GCLA - $12 \cdot 888$

\title{
UNIVERSITY OF CALIFORNIA, LOS ANGELES
}

\section{LABORATORY OF NUCLEAR MEDICINE AND RADIATION BIOLOGY CONTRACT NO. AT (04-1) GEN-12}

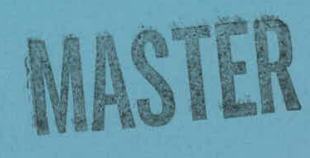




\section{DISCLAIMER}

This report was prepared as an account of work sponsored by an agency of the United States Government. Neither the United States Government nor any agency Thereof, nor any of their employees, makes any warranty, express or implied, or assumes any legal liability or responsibility for the accuracy, completeness, or usefulness of any information, apparatus, product, or process disclosed, or represents that its use would not infringe privately owned rights. Reference herein to any specific commercial product, process, or service by trade name, trademark, manufacturer, or otherwise does not necessarily constitute or imply its endorsement, recommendation, or favoring by the United States Government or any agency thereof. The views and opinions of authors expressed herein do not necessarily state or reflect those of the United States Government or any agency thereof. 


\section{DISCLAIMER}

Portions of this document may be illegible in electronic image products. Images are produced from the best available original document. 
INFLUENCE OF ORGANIC MATTER ON THE

AVAILABILITY OF CERTAIN ELEMENTS TO

BARLEY SEEDLINGS GROWN BY A

MODIFIED NEUBAUER METHOD

H. NISHITA, R. M. HAUG, AND G. V. ALEXANDER

Laboratory of Nuclear Medicine and Radiation Biology

University of California, Los Angeles, CA. 90024

\section{ACKNOWLEDGEMENTS}

These studies were supported by Contract AT(04-1) GEN-12 between the Atomic Energy Commission and the University of California.

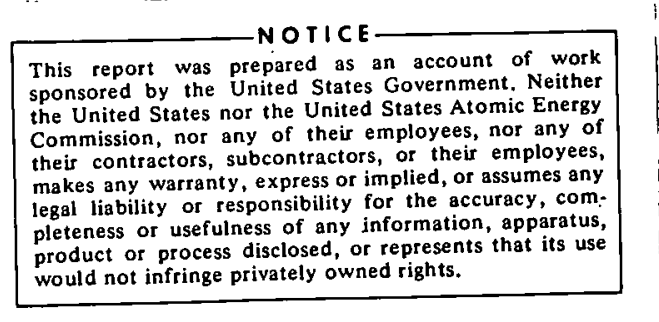


Short Title: INFLUENCE OF ORGANIC MATTER IN SOILS

Number of text pages.............................. 26

Number of tables............................... 5

Number of figures................................ 5

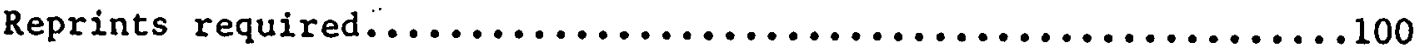


FIGURE CAPTIONS

Fig. 1. Effects of organic matter concentration and incubation time before cropping on the average yields of barley seedlings .

Fig. 2. Average concentrations of $N, P, A 1$, and $S i$ in barley seedlings.

Fig. 3. Average concentrations of $\mathrm{Na}, \mathrm{K}, \mathrm{Mg}, \mathrm{Ca}, \mathrm{Sr}$, and $\mathrm{Ba}$ in barley seedlings.

Yig. 4. Average concentrations of $\mathrm{B}, \mathrm{Cu}, \mathrm{Zn}, \mathrm{Fe}, \mathrm{Mn}$, and Mo in barley seedlings.

Fig. 5. Average $\mathrm{Cs}^{137}$ contents of barley seedlings in relation to incubation time before cropping. 


\section{INFLUENCE OF ORGANIC MATTER ON THE AVAILABILITY}

OF CERTAIN ELEMENTS TO BARLEY SEEDLINGS GROWN

BY A MODIF IED NEUBAUER METHOD

H. NISHITA, R. M. HAUG, AND G。V. ALEXANDER

Laboratory of Nuclear Medicine and Radiation Biology

University of California, Los Angeles, C.A. 90024

SUMMARY

The influence of organic matter on the availability of 17 elements ( $\mathrm{Na}, \mathrm{K}, \mathrm{Cs}^{137}, \mathrm{Mg}, \mathrm{Ca}, \mathrm{Sr}, \mathrm{Ba}, \mathrm{N}, \mathrm{P}, \mathrm{B}, \mathrm{Cu}, \mathrm{Zn}, \mathrm{Fe}, \mathrm{Mn}$, Mo, Al, and $\mathrm{Si}$ ) to barley seedlíngs grown by a modified Neubauer technique was determined. Three different soils that were treated with dry ground mustard spinach leaves ( $1 \mathrm{~g} / 100 \mathrm{~g}$ soil) and incubated for various lengths of time $(0,1,2,5,9,13$, and 17 weeks) in moist condition before cropping were used for this study.

The addition of organic matter to the soils increased the plant yields. The average $N$ and $K$ concentrations were consistently increased in the plants grown in soils with added organic matter. The average concentration of $\mathrm{B}, \mathrm{P}, \mathrm{Na}, \mathrm{Mg}, \mathrm{Sr}, \mathrm{Ba}$, and $\mathrm{Si}$ were almost consistently decreased in the plants. The average contents of $\mathrm{Cu}, \mathrm{Zn}, \mathrm{Fe}, \mathrm{Mn}, \mathrm{Mo}, \mathrm{Ca}$, and $\mathrm{Al}$ varied with the soil types and precropping incubation time. The average $\mathrm{Cs}^{137}$ contents of the plants were reduced considerably by the addition of organic matter to the soils. The reduction of $\mathrm{Cs}^{137}$ contents ranged from 29 to 75 per-cent, depending on the pre-cropping incubation time and soil type. The main factors causing this reduction were considered to be microbial immobilization, ion antagonism 
by $K$, "carbohydrate dilution", and the state of decomposition and the kind of organic matter added to the soils.

\section{INTRODUCTION}

It is well recognized that soil organic matter, together with associated microorganisms, play an important role in the availability of mineral ions to plants. In addition to those released by weathering of inorganic materials, the breakdown of organic matter in the soil releases a number of different elements. The released elements may or may not be readily available to plant roots because of the influence of soil microorganisms and colloids. A number of reviews of soil organic matter are available in the literature $\begin{array}{llllllll}5 & 9 & 19 & 24 & 28 & 35 & 45\end{array}$

This paper shows the influence of organic matter on the availability of 17 elements ( $\mathrm{Na}, \mathrm{K}, \mathrm{Cs}^{137}, \mathrm{Mg}, \mathrm{Ca}, \mathrm{Sr}, \mathrm{Ba}, \mathrm{N}$, $P, B, C u, Z n, F e, M n, M o, A l$, and $S i$ ) to barley seedlings grown by a modified Neubauer technique. A particular emphasis is placed on the availability of $\mathrm{Cs}^{137}$ because of our interest in the behavior of radionuclides, particularly long-lived fission products, that occur in soils as contaminants in tracer amounts. MATERIALS AND METHODS

The soils used in this investigation were Hanford sandy loam, Vina loam, and Aiken clay loam. Their chemical and physical properties are shown in Table 1.

The soils were prepared for plant growth as follows. Under treatment I, 100-g aliquots of solls placed in Pyrex deep pie 
dishes (painted with an opaque plastic base paint) were contaminated with carrier-free $\mathrm{Cs}^{137}$ (118 dis/sec/g) in $6.5 \mathrm{ml}$ volumes of aqueous solution, mixed thoroughly and allowed to air dry. The air-dried contaminated soils were then brought to field capacity with distilled water and incubated in moist condition at room temperature $\left(23^{\circ} \mathrm{C}\right)$ for various lengths of time $(0,1$; $2,5,9,13$, and 17 weeks) before cropping. Under treatment II, the soils were contaminated in the same manner as above. Then one $g$ of dried uncontaminated mustard spinach leaves ground in a Wiley mill to pass through a 40-mesh screen was added to each dish before adding the water. The soils of treatment III were prepared by adding one $\mathrm{g}$ of dried $\mathrm{Cs}^{137}$ contaminated, ground mustard spinach leaves, whose radioactivity was $1.18 \times 10^{4}$ $\mathrm{dis} / \mathrm{sec} / \mathrm{g}$. Note that the application level of $\mathrm{Cs}^{137}$ was the same whether it was in the solution or the organic form. A11 treatments were replicated 5 times. The $\mathrm{Cs}^{137}$ contaminated and uncontaminated mustard spinach were obtained by growing the plants in a modified Hoagland!s nutrient solution with and without $\mathrm{Cs}^{137}$.tracer. The_average chemical composition of the mustard spinach leaves applied to the soils is shown in Table 2. Only one set of data is given, because except for $\mathrm{Cs}^{137}$, the leaf elemental contents were not significantly different. During the incubation periods, the water that was lost by evaporation was replenished by weight twice a week. The different incubation treatments were started at the appropriate times, so that all of the treated soils were cropped simultaneously 
in the same plant growth chamber. The soils were cropped by the Neubauer Technique 26 modified to. use barley seedlings (Hordeum vulgare, va. Atlas) instead of rye seedlings. The cropping period was 22 days.

All $\mathrm{Cs}^{137}$ radio-assays were done in duplicate with a low background gas-flow detector system (150 $\mathrm{mg} / \mathrm{cm}^{2}$ mica window) having an efficiency of 16 per cent for $\mathrm{Cs}^{137}$. Appropriate corrections for counting efficiency, self-absorption and decay were made on all samples. The $\mathrm{N}$ analyses were performed with Coleman Nitrogen Analyzer II (Model 29A) on $0.1 \mathrm{~g}$ aliquots of pulverized plant material. The remaining elements (Na, $\mathrm{K}, \mathrm{Mg}$, $\mathrm{Ca}, \mathrm{Sr}, \mathrm{Ba}, \mathrm{P}, \mathrm{B}, \mathrm{Cu}, \mathrm{Zn}, \mathrm{Fe}, \mathrm{Mn}, \mathrm{Mo}, \mathrm{Al}$ and $\mathrm{Si}$ ) were determined with the use of 1.5 meter, direct reading emission spectrometer (Applied Research Laboratories).

\section{RESULTS AND DISCUSSION}

Figure 1 shows the average yields of the barley tops produced under the different treatments. The yields of the plants grown in the soils receiving no additional organic matter (treatment I) were in the following order: Aiken c.1. < Hanford s.1. < Vina 1. The yield differences between these soils were statistically significant at the 1 per cent level. For any given soil, the yields of the treatment I plants were significantly ( 1 per cent level) lower than those of the treatment II or III plants, which were grown in soils treated with additional organic matter. Thus, the application of organic matter to the soils had a beneficial 
effect on plant growth.

A comparison of plant yields between treatments II and III for Hanford s.1. or Vina 1. showed no difference at the 5 per cent level of significance. For some undetermined reason, the same comparison for Aiken c.l. showed that the treatment II plant yields were significantly lower than that of treatment III under 5-, 9-, and 13-week pre-cropping incubation conditions. In any case, among the 3 soils treated with organic matter, Vina 1. showed significantly ( 1 per cent level) greater plant yields than Hanford s.1. or Aiken c.1. With the exceptions mentioned above, the plant yields for the organic matter treated Aiken c.l. were not significantly different from that for Hanford s.1.

When simple salt fertilizers are added to soils the increases of plant yields may be ascribed to the increased availability of one limiting element that was applied. However, the increases of plant yields caused by the application of organic matter are not readily ascribable to the increased availability of a particular element, since the availability of several elements may be increased. The influences of the organic matter application on the elemental contents of the barley seedlings are shown in figures 2,3 , and 4 . The average $N$ and $K$ contents were consistently increased, irrespective of soil type or pre-cropping incubation time. - (The data for treatment III only are compared with those of treatment I, since the differences between treatments 
II and III were very small, if there were any differences at a11). The average contents of $\mathrm{B}, \mathrm{P}, \mathrm{Na}, \mathrm{Mg}, \mathrm{Sr}, \mathrm{Ba}$, and $\mathrm{Si}$ were almost consistently decreased. The average contents of $\mathrm{Cu}, \mathrm{Zn}, \mathrm{Fe}, \mathrm{Mn}, \mathrm{Mo}, \mathrm{Ca}$, and $\mathrm{Al}$ appeared to vary considerably with the soil type and pre-cropping incubation time. As ind1cated by the relatively large standard deviation, the variability of the majority of the latter group of elements within any given treatment was greater than those of other groups of elements. A summary of the statistical test of difference ( 5 per cent level of significance) between the elemental concentrations of the treatment-I and -III plants is given in Table 3.

The increased availability of the first group of elements ( $N$ and $K$ ) is ascribed to their release from the decomposing organic matter over and above that immobilized by microorganisms. of the 2 elements in this group, $N$ very likely was the more important one in increasing the plant yields. Potassium is considered to be of lesser importance, because it was not limiting. Its extractable form. (Table 1) was sufficiently high in the solls even before the application of organic matter. The degree of $\mathrm{K}$ saturation of the soil exchange complexes ranged from 3.3 to 9.5 per cent.

The reduced availability of the second group of elements (B, P, Na, Mg, Sr; Ba, and Si) to plants is considered to be due primarily to microbial immobilization. This implies that the available concentrations of this group of elements were not 
sufficiently high to overcome the effect of microbial immobilization. Microbial immobilization is surmised from the fact that the microbial population in the soil increases greatly upon the addition of undecomposed organic matter ${ }^{39}$. In accumulating the available ions, the microorganisms have an overwhelming advantage, because they are at the very site at which the decomposition of organic matter occurs and available ions are $\therefore$ released. Because of their tremendous number and their minute size, it is reasonable to assume that they also present much larger surface within a given soil bulk from which ions are adsorbed and/or absorbed. Microorganisms also produce metabolically active substances that can influence the rate of ion uptake by the plants ${ }^{29}$. Barber ${ }^{2}$ has reviewed the effects of microorganisms on the absorption of ions by plants.

It was noted above that the third group of elements ( $\mathrm{Cu}$, $\mathrm{Zn}, \mathrm{Fe}, \mathrm{Mn}, \mathrm{Mo}, \mathrm{Ca}$, and $\mathrm{Al}$ ) showed considerable variability. Perhaps, the notable elements of this group are Mn and Mo. The average Mn contents of the plants grown in Aiken c.1. with added organic matter were consistently decreased, whereas they varied with the pre-cropping incubation time of the other soils. The average plant contents of Mo were consistently increased with Hanford s.1. and decreased with Aiken c.1. With Vina 1., its plant contents varied with pre-cropping incubation time. In general, the variable behavior of this group of elements is not readily explainable. Part of the variability could be due 
to microbial activity. A certain amount of microbial immobilization must certainly occur since all elements in this group, except A1, are essential nutrient elements. Other factors that could be involved are the plant absorption characteristics of the elements and the interaction of the elements with the soil. The Ca data perhaps illustrate the latter factor in operation. The Ca uptake by the plants was less from Vina 1. than from Hanford s.1. or Aiken c.1., even though its extractable Ca (Table 1) was greater than that for the latter soils. This effect could be explained, at least in part, by the degree of Ca saturation in the exchange complex of the solls and the predominant clay minerals in the soils. A number of investigators have shown that cation availability to plants is affected by the nature of the exchange materials in soils and their degree of cation saturation 471112303142 . The change of soil $\mathrm{pH}$ as a result of organic matter mineralization could also have an effect. The data of Wallace et al. 44 show that the addition of organic matter could increase the soil pH by 0.5 unit or more. This, however, should be interpreted in the light of the amount of organic matter added and the kind of soil used, since different soils have different buffer capacity.

Figure 5 shows that the average $\mathrm{Cs}^{137}$ contents of the barley seedlings were reduced considerably by the addition of organic matter to the soils. Depending on the pre-cropping incubation time, the percentage reduction of the average contents ranged 
from 29 to 47,52 to 59, and 34 to 75 for Hanford s.1., Vina 1 . and Aiken c.l., respectively. With Hanford s.1. and Vina 1., the difference of the average $\mathrm{Cs}^{137}$ contents between treatments II and III were insignificant. With Aiken c.1., the average Cs 137 contents are shown to be definitely reduced under treatment III for the 5-, 9-, and 13- week pre-cropping incubation periods for an undetermined reason. A summary of the statistical test of difference ( 5 per cent level) of $\mathrm{Cs}^{137}$ contents of the barley seedlings as influenced by organic matter treatment, Incubation time, and interaction is given in Table 4: Obviously, there were several significant effects depending on the soil. In any case, the important point is that the application of organic matter to the soils significantly reduced the Cs ${ }^{137}$ uptake by plants.

At least three factors played some role in reducing the $\mathrm{Cs}^{137}$ uptake by the plants. One factor was certainly microbial immobilization mentioned above. Since $\mathrm{Cs}^{137}$ occurred only in tracer quantity in the soils, the ratio of the number of $\mathrm{Cs}^{137}$ ions to the number of microbial cells was relatively very small. Thus, microbial immobilization should be quite effective. Ion antagonism by $K$ was very likely another factor, because as indi:cated by appreciably increased $K$ uptake by the plants (figure 3), the available $\mathrm{K}$ in the soils was increased. This resulted in the marked decrease of $\mathrm{Cs}^{137} / \mathrm{K}$ atom ratios in the plants (Table 5). The depressive effect of $K$ on $C s$ uptake by plants has been well 
established by solution culture studies $181422 \quad 2533 \quad 3437$ and soil culture cxperiments $15-1827324041$. Another factor may be "carbohydrate dilution," since plant growth was increased by the addition of organic matter (figure 1 ). This factor probably functioned also to some extent in causing the reduction of the uptake of several-stable elements mentioned above. It has been reported that extractable $\mathrm{Ca}$ in the soil has a depressing effect on the accumulation of $\mathrm{Cs}^{137}$ in the plant ${ }^{16}$. In the present experiment, the effect of $\mathrm{Ca}$ appeared to have varied, since the available $\mathrm{Ca}$ was reduced in certain cases and increased in others (figure 3 ).

\section{GENERAL DISCUSSION}

Barber ${ }^{3}$ found that $\mathrm{Cs}^{137}$ uptake by ryegrass was greater from soils that were higher in organic matter content, and has pointed out that when organic matter is responsible for a large fraction of the total exchange capacity of the soil, the adsorption and subsequent fixation of $\mathrm{Cs}^{137}$. on the clay minerals are much reduced. Part of this effect may be explained by the fact that organic matter could be adsorbed in the interlayers of the clay minerals 132021233643 . The adsorption of : organic matter in effect tends to reduce the fixation of $\mathrm{Cs}^{1.37}$ by blocking action. Another factor playing a role here may be the exchangeable K. Eagle ${ }^{10}$ has shown that the greater the organic matter content of the soil the higher the level of exchangeable $K$. This latter effect was also shown in our recent work ${ }^{38}$. 
Consequently, the competitive effect of exchangeable $\mathrm{K}$ may work in conjunction with organic matter adsorption in reducing Cs 137 fixation. The high availability of $\mathrm{K}$ reduces the $\mathrm{Cs}^{137}$ fixation on the soil clay minerals. This in turn increases the Cs 137 availability to plant roots. However, the high availability of $\mathrm{K}$ also increases the competitive action of $\mathrm{K}$ on $\mathrm{Cs}^{137}$ uptake by plant roots. Thus, the $\mathrm{Cs}^{137}$ absorbed by the plants is the net result of opposing effects.

The difference between Barber's results ${ }^{3}$ and the results of the present experiment, which showed reductions of $\mathrm{Cs}^{137}$ uptake by the plants grown in soils with added organic matter, suggests that there were influencing factors in addition to those discussed above. The important ones of these may be the state of decomposition and the kind of organic matter added to the soils. These factors determine the amount of different kinds of microorganisms that can absorb the tracer Cs ${ }^{137}$. In Barber's experiment ${ }^{3}$, the soils, having received no fresh added organic matter, probably consisted primarily of humus and products of advanced decomposition of organic residues and products resynthesized by microorganisms. The soils of the present experiment contained these substances and the partially decomposed plant material that was added. Under the latter condition, there would be a flush of growth of microbial population, which would increase the amount of microbial immobilization of $\mathrm{Cs}^{137}$.

The application of organic matter to the soils used was in general beneficial in that the plant yields were increased. 
From the data avalable, it is difficult to state definitely which element had the greatest effect in causing the yield increases. However, it is surmised that $\mathrm{N}$ had the greatest effect. In other words, the organic material added probably was important primarily as a source of $\mathrm{N}$.

\section{ACKNOWLEDGEMENTS}

These studies were supported by Contract AT(04-1) GEN-12 between the Atomic Energy Commission and the University of California. 
LITERATURE CITED

I Bange, G。G.J. and Overstreet, R., Some observations on absorption of cesium by excised barley roots. Plant Physiol. $35,605-608(1960)$.

2 Barber, D. A., Microorganisms and the inorganic nutrition of higher plants. Ann. Rev. Plant Physiol. 19, 71-88 (1968).

3 Barber, D. A., Influence of soil organic matter on the entry of caesium-137 into plants. Nature 204, 1326-1327 (1964).

4 Benson, D. W. and Toth, S. J., Availability of $\mathrm{Ca}$ and $\mathrm{K}$ adsorbed on clay minerals and soils. Sol1 Sci. 95:196-203 (1963).

5 Bremner, J. M., Review of recent work in soil organic matter: I. Soil Sci. 2, 67-82 (1951).

6 Broadbent, F. E., The soil organic fraction. Adv. Agron. 5, $153-183$ (1953).

7. Chu, T. S: and Turk, I. M., Growth and nutrition of plants as affected by degree of saturation and different types of clay minerals. Michigan Agr. Expt. Sta. Bull. 214 (1949).

8 Cline, J. F. and Hungate, F. P., Accumulation of potassium, cesium-137 and rubidium-86. in bean plants grown in nutrient solutions. Plant Physiol. 35, 826-829 (1960).

9 Dawson, J.E., Agricultural Chemistry. D. Van Nostrand Co., Inc., New York, N. Y., Vol. 1, pp. 778-797 (1950).

10 Eagle, D. J., Potassium availability to plants. Nature $198,558-560(-1963)$ 
11 Eck, P., Drake, M., and Steckel, J. E., Calcium uptake by tomatoes as influenced by the native and per cent calcium saturation of $\mathrm{Ca}-\mathrm{H}$ clay systems. Soil Sci. 84:145154 (1957).

12 Elgabaly, M. M. and Willander, L., Effect of exchange capacity of clay mineral and acidoid content of the plant on uptake of $\mathrm{Na}$ and $\mathrm{Ca}$. by excised barley and pea roots. Soil Sc1. 67:419-424 (1949).

13 Ensminger, L. E. and Gieseking, J. E., The adsorption of proteins by montmorillonite clays and its effect on base exchange capacity. So11 Sci. 51, 125-132 (1941).

14 Epstein, E. and Hagen, C. E., A kinetic study of the absorption of alkali cations by barley roots. Plant Physiol. 27, 457-474 (1952).

15 Fredriksson, L., Studies on plant absorption of ${ }^{90} \mathrm{Sr}$ and ${ }^{137}$ Cs from some tropical and subtropical soils. FOA 4 Rapport A 4319-4623, Forsvarets Forskningsanstalt Avdelning 4, Stockholm, Sweden (1963).

16 Fredriksson, L., Studies on plant accumulation of fission products under Swedish condtions. IV. Influence of exchangeable and nonexchangeable potassium and of exchangeable calcium in soil on the absorption of ${ }^{137} \mathrm{Cs}$ by red clover in pot experiments with 178 Swedish soils。 FOA 4 Rapport A 4321-4623, Forsvarets Forskningsanstalt Audelning 4, Stockholm, Sweden (1963). 
17. Fredriksson, L. and Eriksson, B., Studies on soil-plantanimal interrelationships with respect to fission products. Plant uptake of $\mathrm{Sr}^{90}$ and $\mathrm{Cs}^{137}$ from soils: In Progress in Nuclear Energy, Series XII, Vol. 1 - Health Physics, Pergamon Press, New York, N. Y. pp. 500-533 (1959).

18 Fowler, E. B. and Christenson, C. W., Effect of soil nutrients on plant uptake of fallout. Science 130, 1689-1693 (1959).

19 Fuller, W. H., Soil Organic Matter. University of Arizona, Bull A-40 (1965).

20 Greenland, D. J., Laby, R. H., and Quirk, J. P., Adsorption of amino acids and peptides by montmorillonite and illite. Part III. Physical adsorption. Trans. Faraday Soc. 61, 2024-2035 (1965).

21 Greenland, D. J. and Quirk, J. P., Adsorption of 1-n-alkyl pyridinium bromides by montmorillonites. Clay and clay Min. 9, 484-499 (1962).

22 Handley, R, and Overstreet, R., Effect of various cations upon absorption of carrier-free cesium. Plant Physiol. 36, 66-69 (1961).

23 Hendricks, S. B., Base-exchange of the clay mineral montmorillonite for organic cations and its dependence upon ádsorption due to Van der Waals forces. J. Phys. Chem. 45, $65-81(1941)$

24 International Atomic Energy Agency, Isotopes and Radiation in Soil Organic-Matter Studies. Proc. Symposium STI/PUB/190, International Atomic Energy Agency, Vienna, Austria (1968). 
25 Jackson, W. A., Lugo, H. M., and Craig, D., Cesium uptake from dilute solutions by young wheat seedlings as affected by selected cations. Plant and Soil XXIV, 33-53 (1966).

26 Kitchen, H. B., ed., Diagnostic techniques for soils and crops. The American Potash Institute, Washington, D. C. (1948).

27 Klechkovsky, V. M., On the behavior of fission products in soil. Acad. Sci. USSR, Translated and published by U.S. Atomic Energy Commission as AEC-TR-2867 (1957).

28 Kononova, M. M., Nowakowski, T. Z., and Newman, A. C. D., Soil Organic Matter. 2nd Edition, Pergamon Press, New York, N. Y. (1966).

29 MacDonald, I. R., Bacterial infection and ion absorption capacity in beet disks. Ann. Bot. (London) 31, 163-172(1967).

30 Mehlich, A. and Colwell, W. E., Influence of nature of soil colloids and degree of base saturation on growth and nutrient uptake by cotton and soybeans. Soil Sci. Soc. Amer. Proc. 8:179-184 (1944).

31 Mehlich, A. and Reed, J.F., The influence of degree of saturation, potassium lével, and calcium additions on removal of calcium, magnesium, and potassium. Soil Sci. Soc. Amer. Proc. 10:87-93 (1946).

32 Menzel, R. G., Competitive uptake by plants of potassium, rubidium, cesium and calcium, strontium, barium from soils. Soil Sci. 77, 419-425 (1954). 
33 Menzel, R. G. and Heald, W. R., Distribution of potassium, rubidium, cesium, calcium and strontium within plants grown in nutrient solutions. Soil Sci. 80, 287-293 (1955).

34 Middleton, L. J., Handley, R., and Overstreet, R., Relative uptake and translocation of potassium and cesium in barley. Plant Physiol: 35, 913-918 (1960).

35 Mortensen, J. L. and Himes, F. L. Soil organic matter. In F. E. Bear, ed. Chemistry of the Soil, Reinhold Publishing Corp., New York, N. Y. pp. 206-241 (1964).

36 Mortland, M. M., Influence of some organic salts on the absorption of potassium of vermiculite. Nature 192, 481482. (1961).

37 Nishita, H., Dixon, D., and Larson, K. H., Accumulation of Cs and $K$ and growth of bean plants in nutrient solution and soils. Plant and Soil XVII, 221-242 (1962).

38 Nishita, H. and Haug, R. M., Distribution of different forms of nitrogen in some desert soils. Soil Sci: Accepted for publication (1973).

39 Nishita, H., Kowalewsky, B. W., and Larson, K. H. Influence os soil organic matter on mineral uptake by barley seedlings. Soil Sci. 82, 307-318 (1956).

40 Nishita, H., Romney, E. M., Alexander, G. V.; and Larson, K. H., Influence of $\mathrm{K}$ and $\mathrm{Cs}$ on release of $\mathrm{Cs}^{137}$ from three soils. Soil Sci. 89, 167-176 (1960). 
41 Nishita, H., Steen, A. J., and Larson, K. H. Release of Sr90 and Cs137 from Vina loam upon prolonged cropping. Soil Sci. 86, 195-201 (1958).

42 Throne, D. W., Growth and nutrition of tomato plants as influenced by exchangeable sodium, calcium, and potassium.

Soil Sci. Soc. Amer. Proc. 9:185-189 (1944).

43 Walker, G. F., Diffusion of exchangeable cations in vermiculite. Nature 184, 1392-1393 (1959).

44 Wallace, A., et al., Regulation of the micronutrient status of plants by chelating agents and other factors. Published by A. Wallace, Los Angeles, California 90024, pp. 17-20 (1971).

45 Whitehead, D. C., Some aspects of the influence-of organic matter on soil fertility. Soils and Fertilizers XXVI, $217-223(1963)$ 
Table 1

Chemical and physical properties of the soils used.

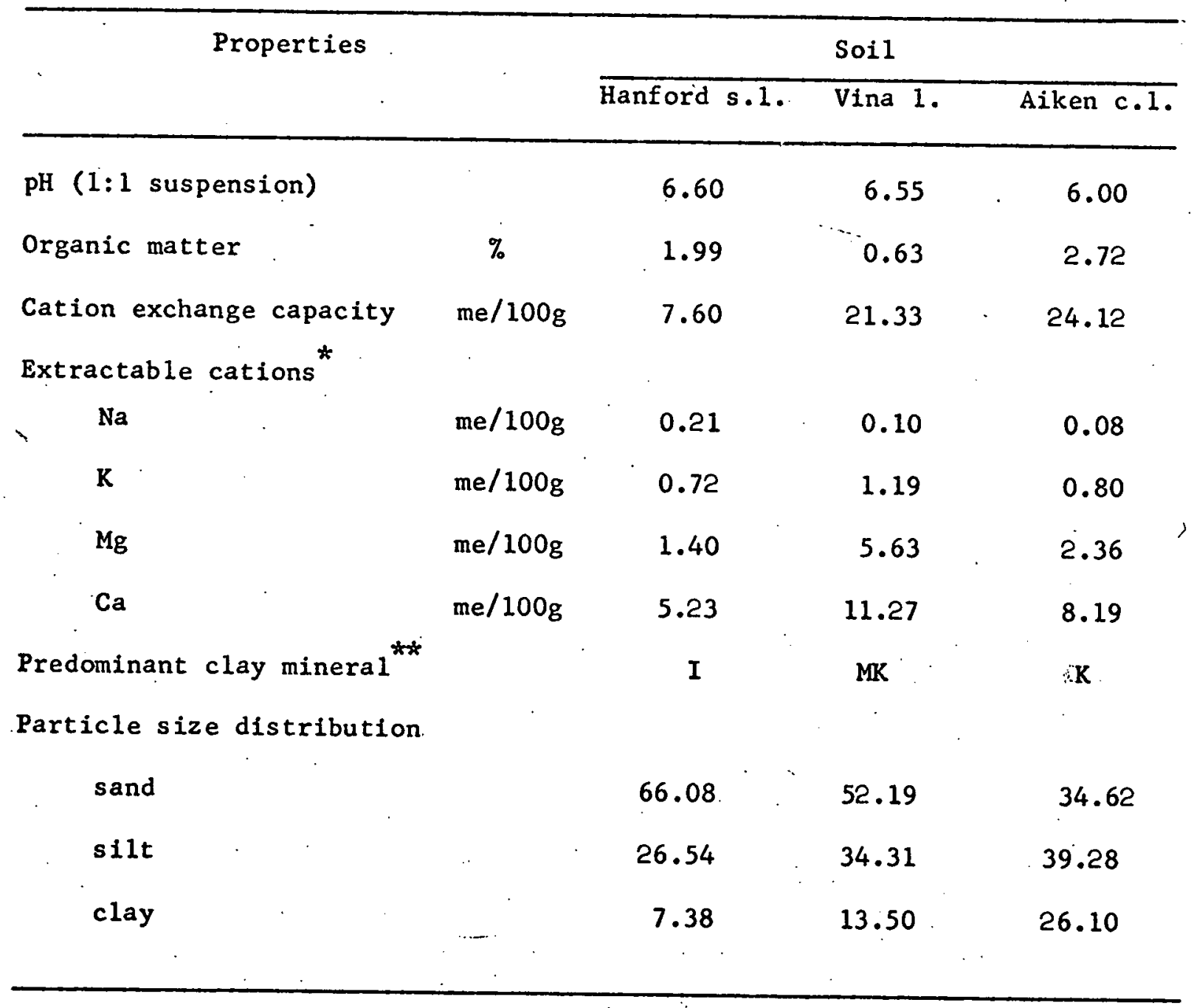

\footnotetext{
*Extractable with neutral normal ammonium acetate: ${ }^{\star *} I=$ illite; $M K=$ montmorillonite and kaolinite; $K=$ kaolinite.
} 
a

Table 2

Average elemental composition of dry, ground mustard spinach leaves applied to the experimental soils.

\begin{tabular}{lrrrrrr}
\hline Element & $\mathrm{mg} / \mathrm{g}$ & Element & $\mu \mathrm{g} / \mathrm{g}$ & Element & $\mu \mathrm{g} / \mathrm{g}$ \\
\hline $\mathrm{N}$ & $64.20(1.50)$ & $\mathrm{Na}$ & $98.20(7.62)$ & $\mathrm{Mn}$ & $111.60(3.26)$ \\
$\mathrm{P}$ & $6.54(0.36)$ & $\mathrm{Zn}$ & $109.20(9.30)$ & $\mathrm{B}$ & $25.10(0.80)$ \\
$\mathrm{K}$ & $48.26(5.36)$ & $\mathrm{Cu}$ & $7.13(0.51)$ & $\mathrm{Mo}$ & $7.17(0.74)$ \\
$\mathrm{Ca}$ & $18.40(0.77)$ & $\mathrm{Fe}$ & $29.70(2.09)$ & $\mathrm{Sr}$ & $1.23(0.12)$ \\
$\mathrm{Mg}$ & $4.43(0.62)$ & & & & &
\end{tabular}

*Values within the parentheses represent one standard deviation. 
Table 3

Sumary of the statistical test of difference ( 5 per cent level of $:$ : significance)between the elemental concentrations of the treatment-I and -III plants.

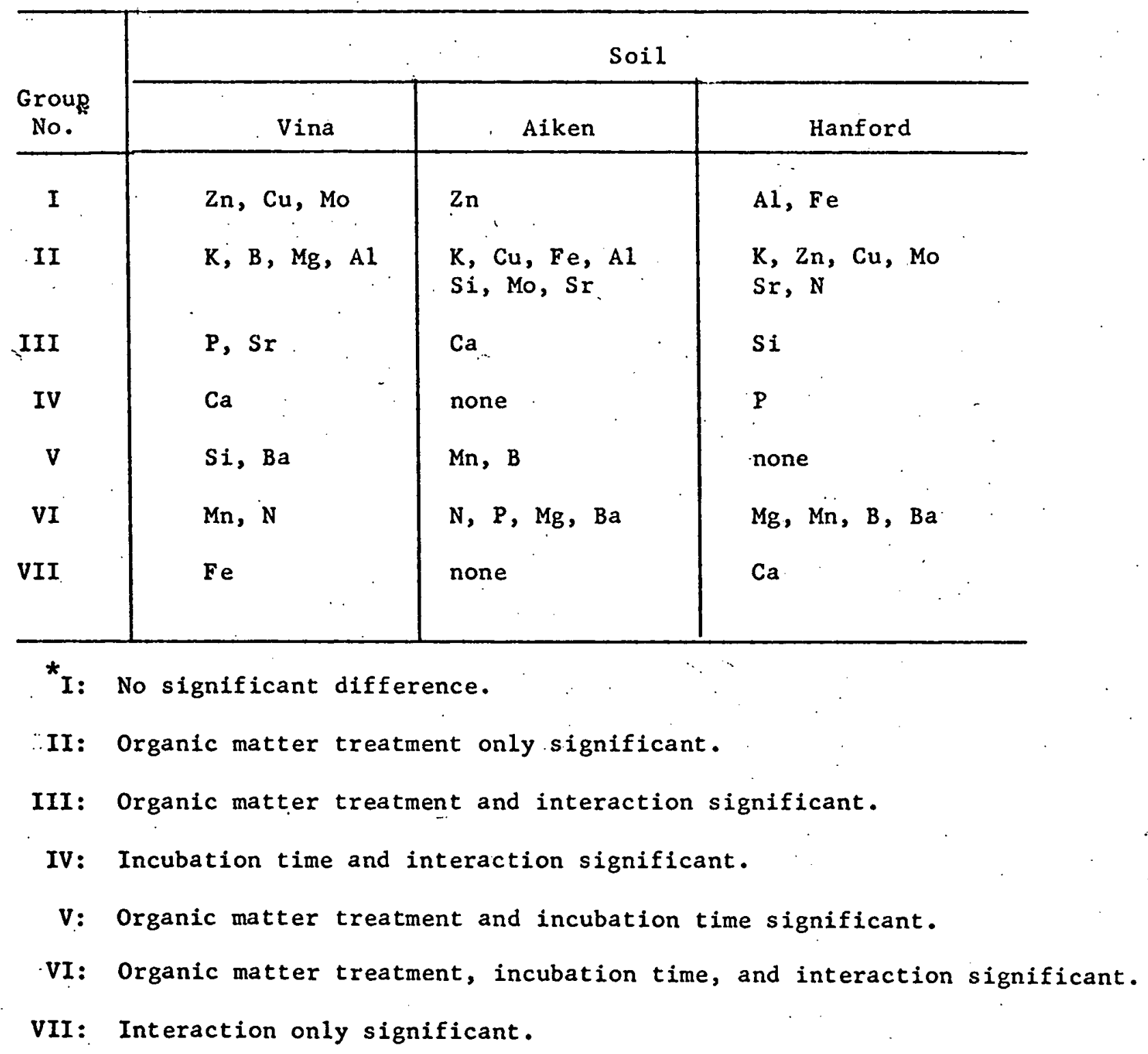


Table 4

Summary of the statistical test of difference ( 5 per cent level of significance) of $\mathrm{Cs}^{137}$ contents of barley seedlings as influenced by $\cdots \cdot \ldots$. organic matter treatment, incubation time; and interaction.

\begin{tabular}{l|c|c|c}
\hline & \multicolumn{2}{|c}{ Soil $^{*}$} \\
\cline { 2 - 4 } Comparison & Vina & Aiken & Hanford \\
\hline Treat. I - Treat. II & A & B & C \\
Treat. I - Treat III & A & C & C \\
Treat. II - Treat. III & D & C & E \\
\hline
\end{tabular}

*A: Organic matter treatment only significant.

B: Organic matter treatment, incubation time, and interaction significant.

C: Organic matter and interaction significant.

D: Incubation time only significant.

E: No significant difference. 
Table 5

$\operatorname{cs}^{137} / 10^{7} \mathrm{~K}$ atom ratios of barley seedlings grown in three soils that were incubated for various lengths of time before cropping.

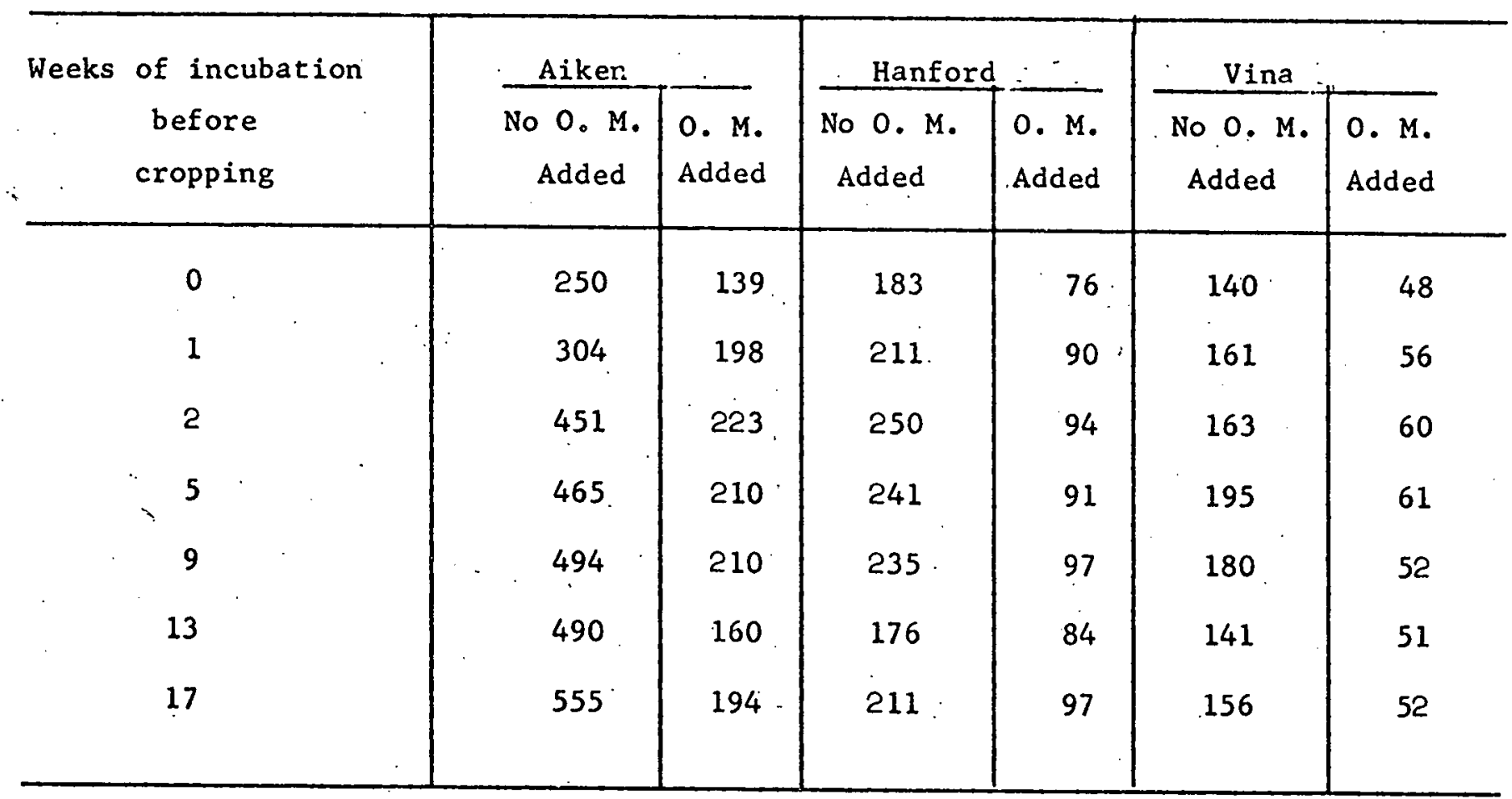

O.M. = organic matter 
Fig. 1. Effects of organic matter concentration and incubation time before cropping on the average yields of barley

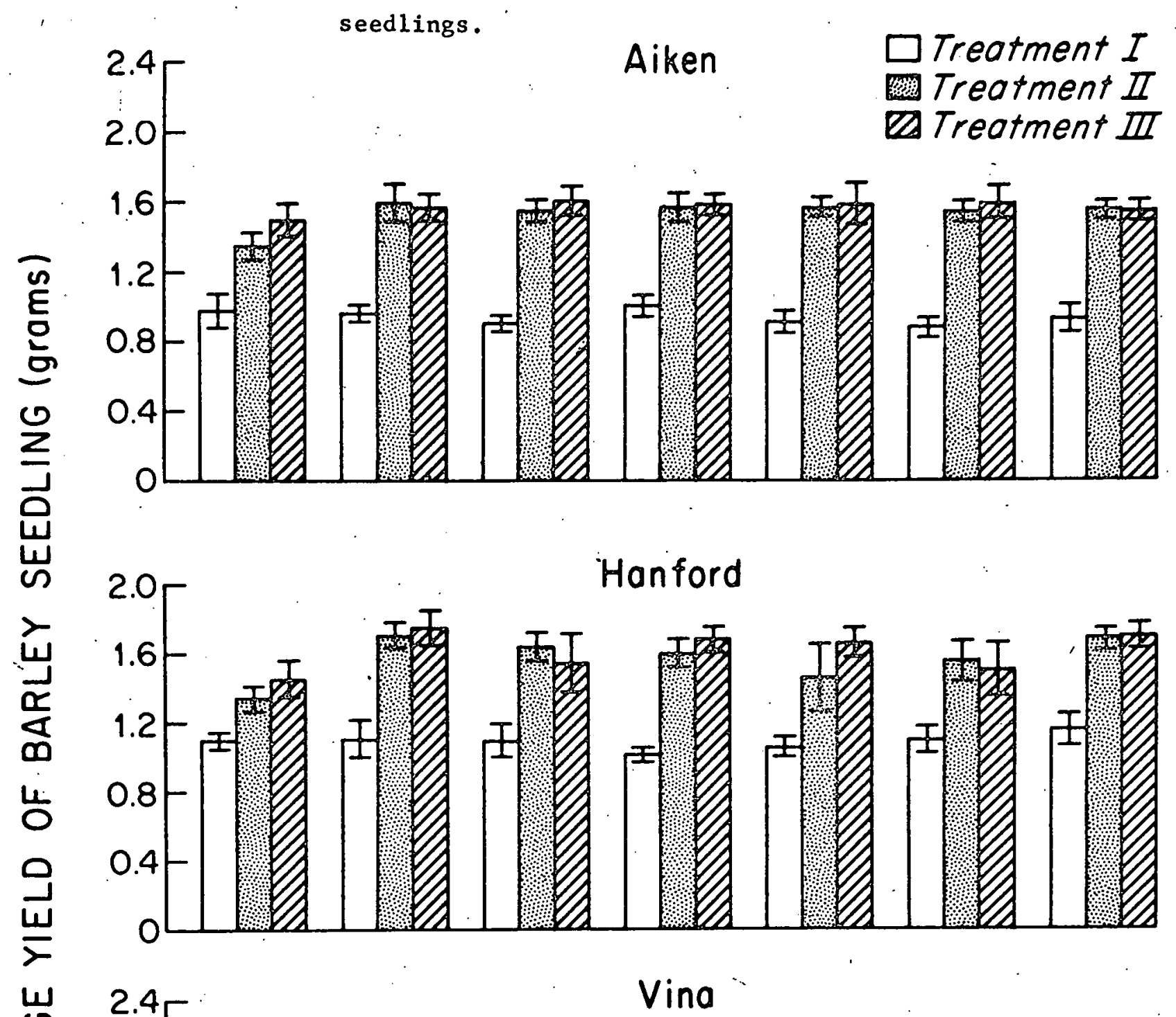

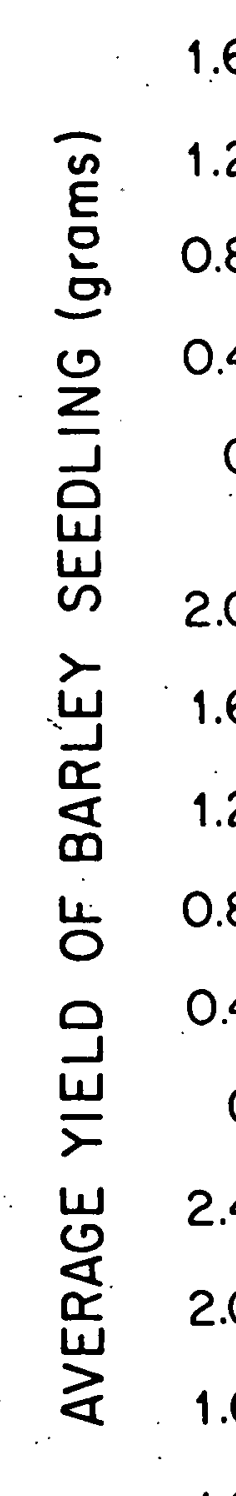
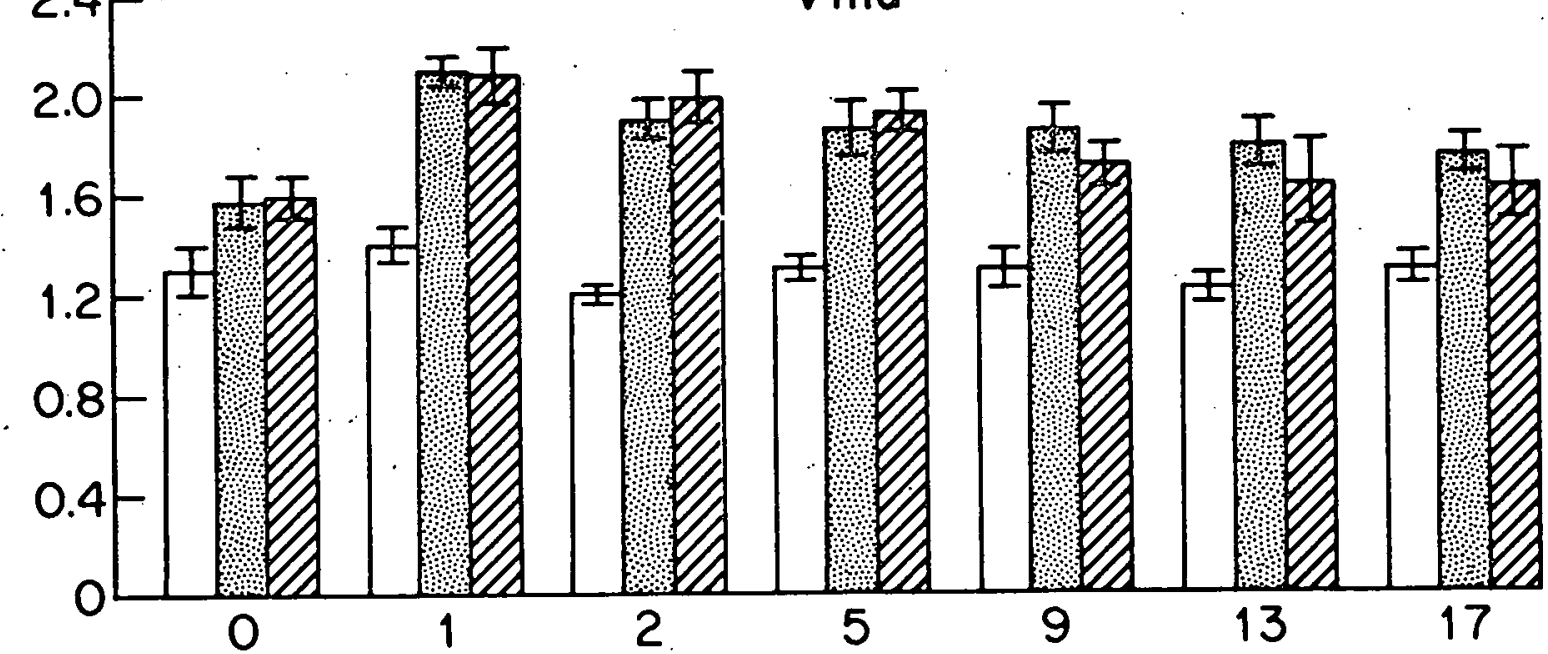

INCUBATION TIME BEFORE CROPPING (WEEKS) 
Fig. 2. Average concentrations of $N, P, A 1$, and $S 1$ in barley seedlings.

\section{VINA}

ミ 30- $\square$ Without Added O.M. (Treat. I)

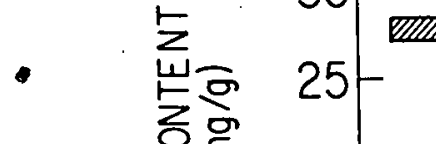

它宝

15 th

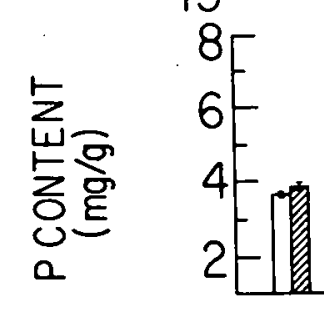
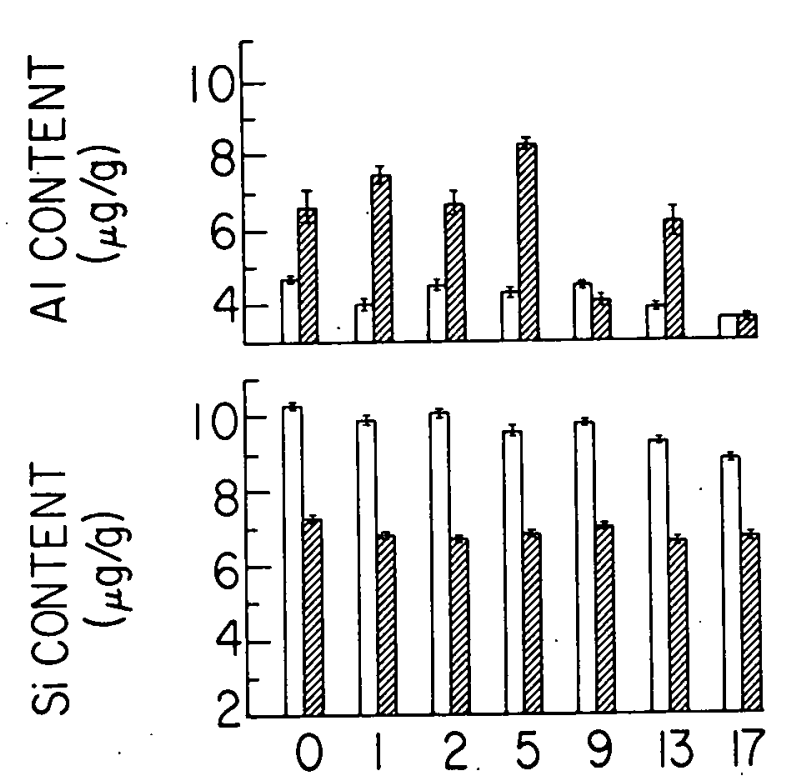

HANFORD

AIKEN
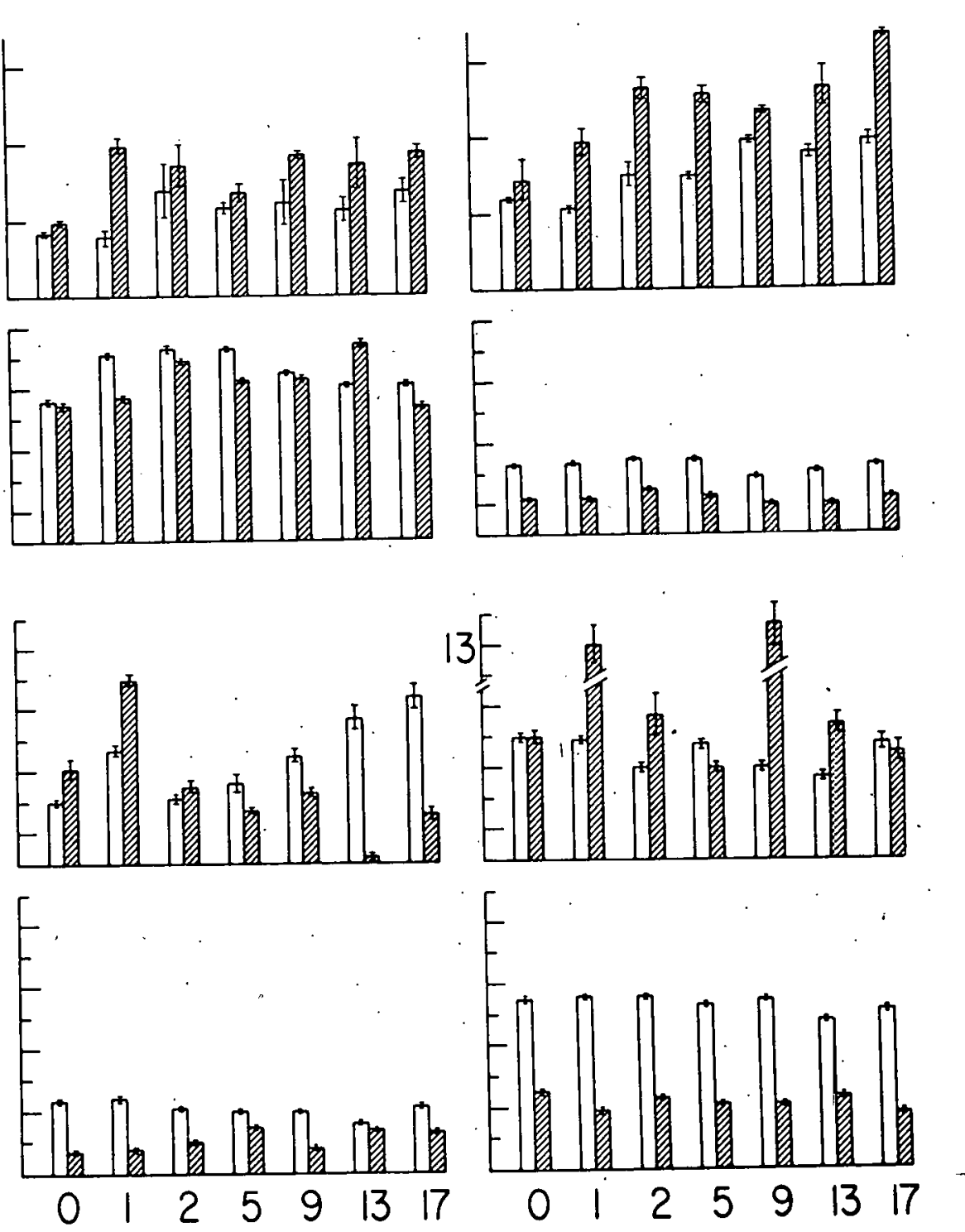

INCUBATION TIME BEFORE CROPPING (weeks) 
Fig. 3." Average concentrations of $\mathrm{Na}, \mathrm{K}, \mathrm{Mg}, \mathrm{Ca}, \mathrm{Sr}$, and $\mathrm{Ba}$ in barley seedlings.

VINA

HANFORD

AIKEN

$\sum_{\text {出 }} 8$ F N.D. No Data

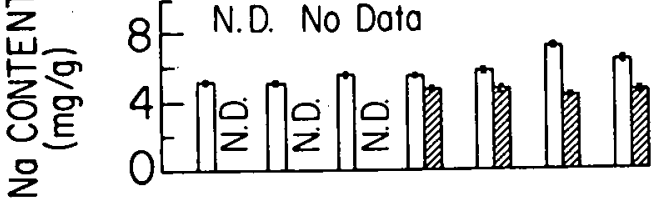
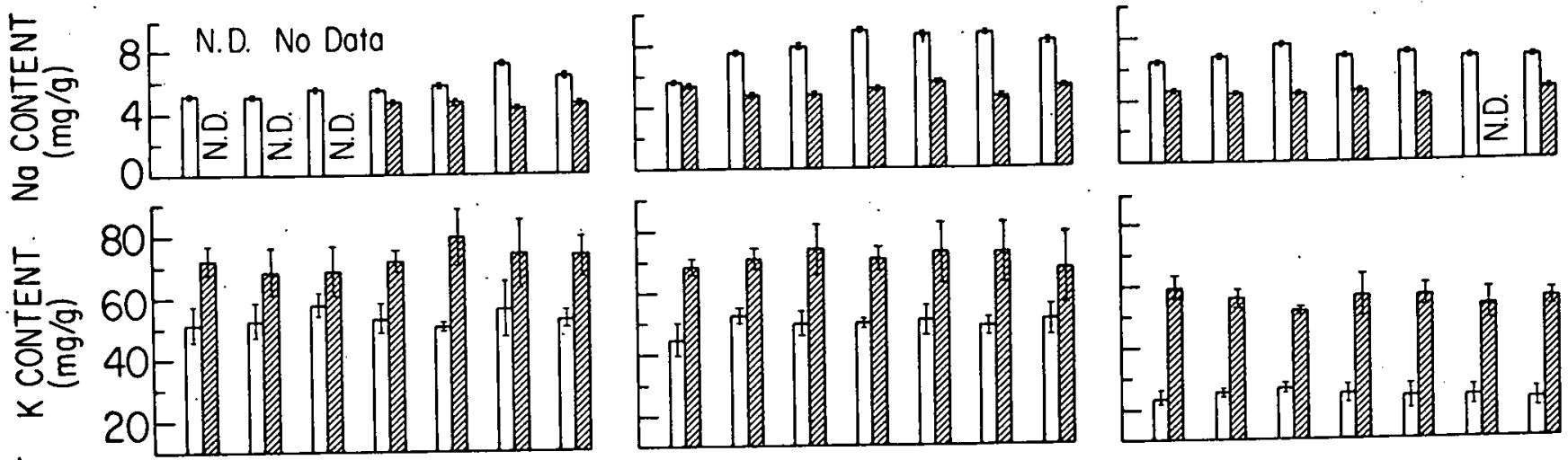

点 6

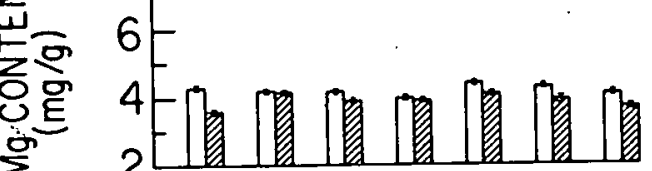

竎可

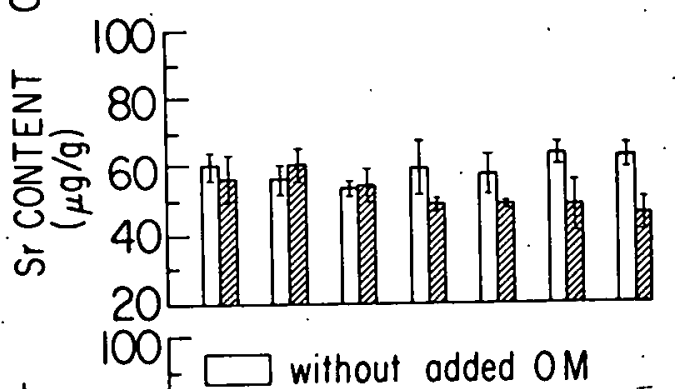

$\sum_{4} 80-$

F

点 60

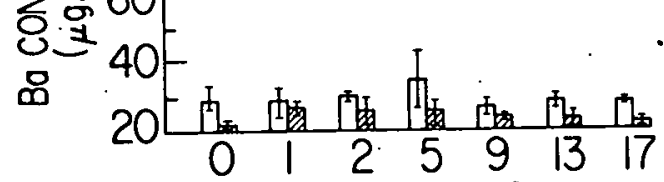
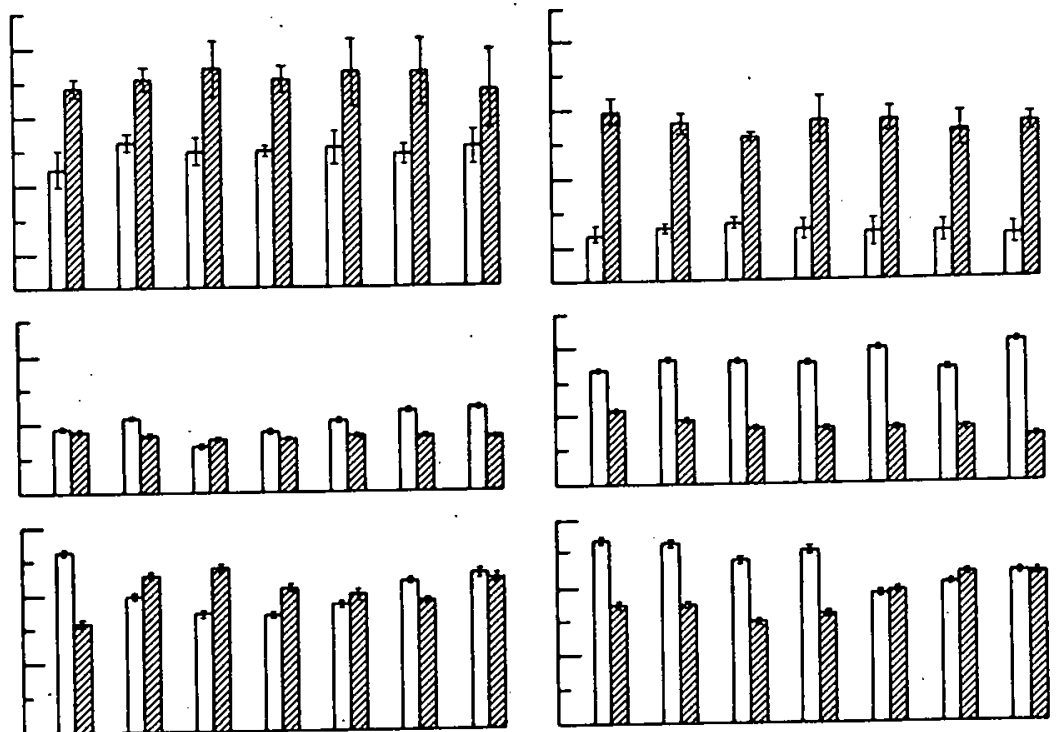

INCUBATION TIME BEFORE CROPPING (weeks)
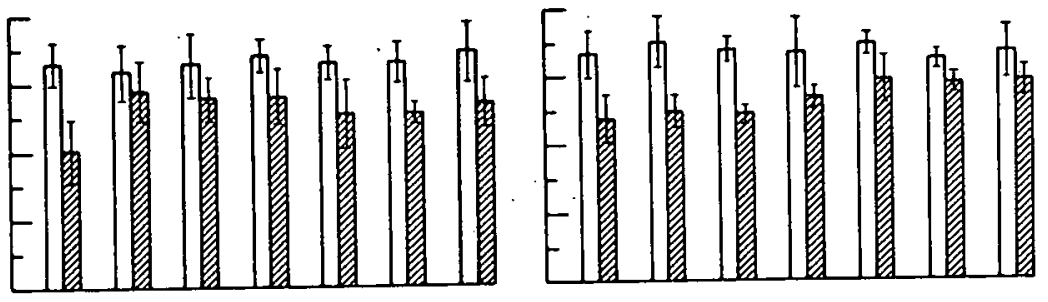

F Wun with added $O M$
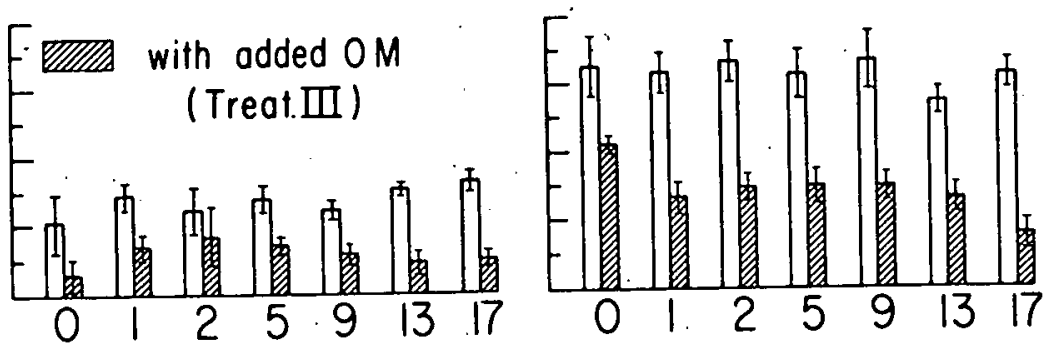
Fig. 4. Average concentrations of $B, \mathrm{Cu}, \mathrm{Zn}, \mathrm{Fe}, \mathrm{Mn}$, and Mo in barley seedlings.

VINA

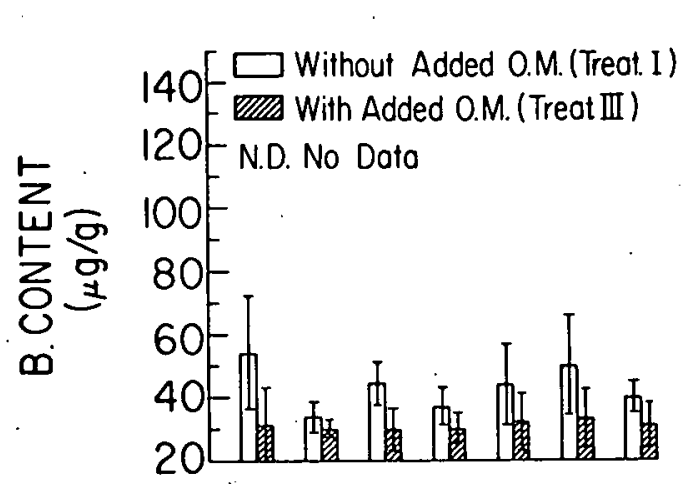

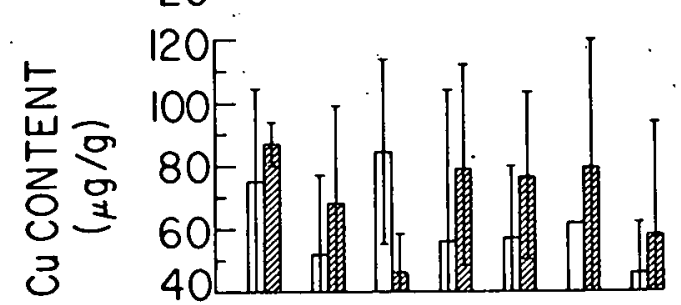

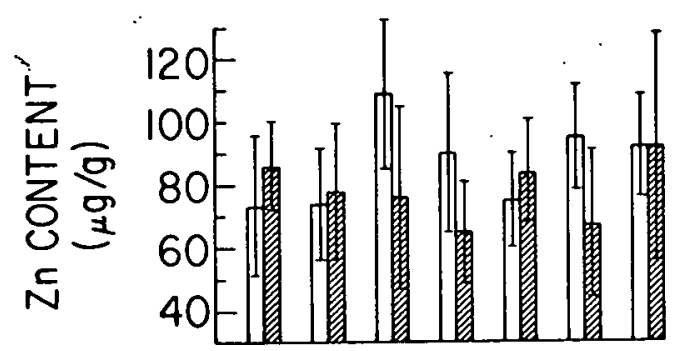

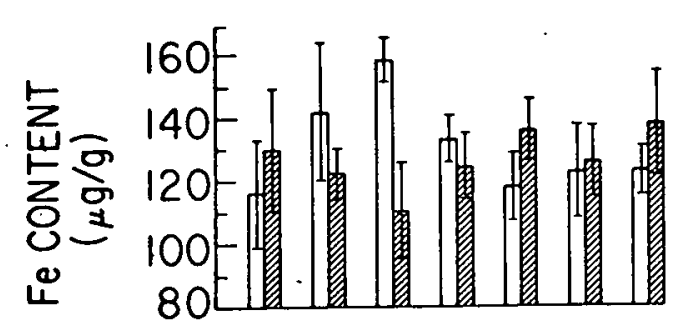

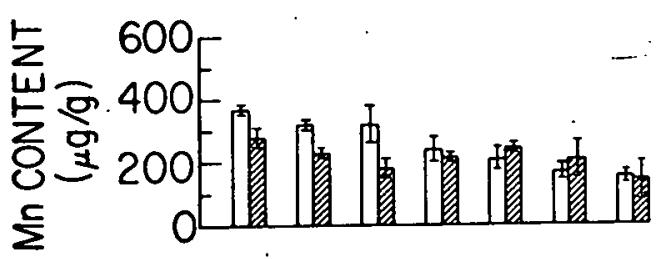

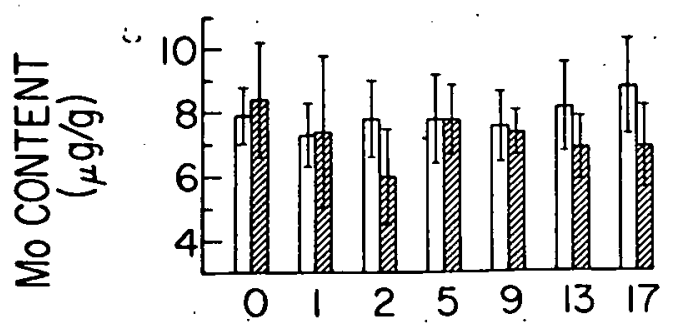

HANFORD
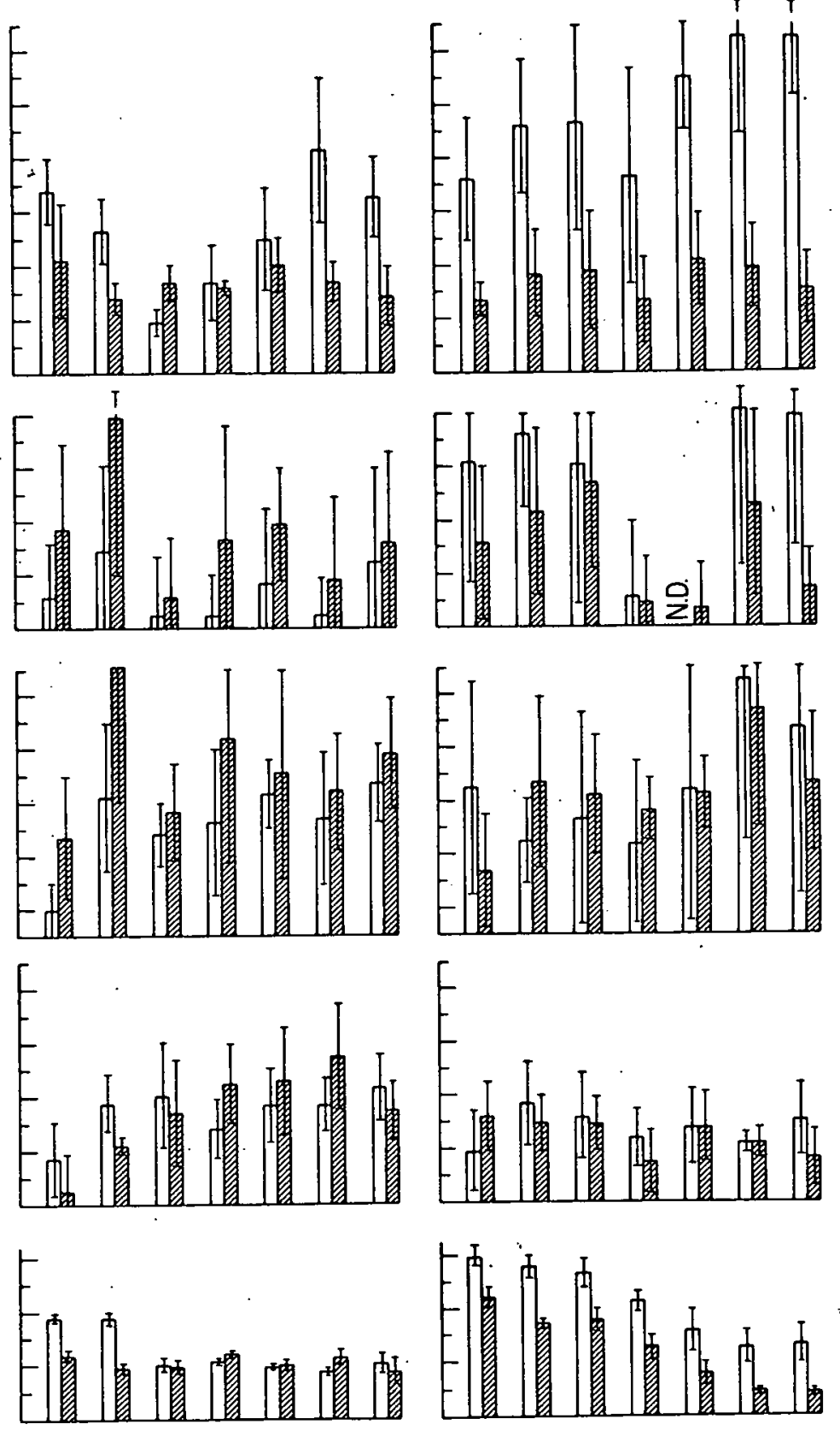

INCUBATION TIME BEFORE CROPPING (weeks)

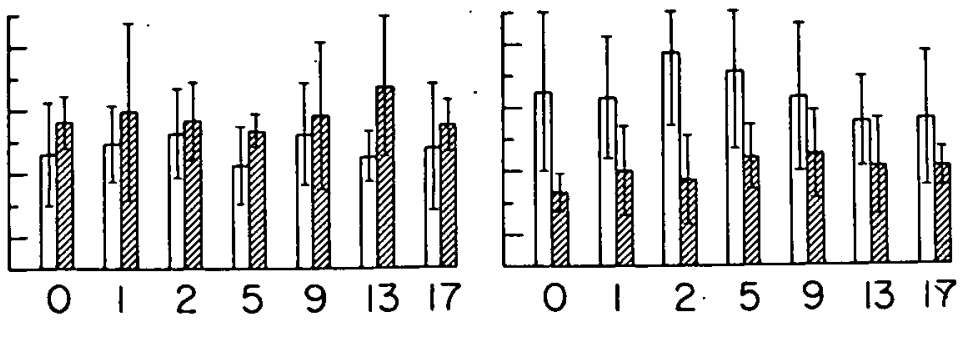


Fig. 5. Average $\mathrm{Cs}^{137}$ contents of barley seedlings in relation to incubation time before cropping.

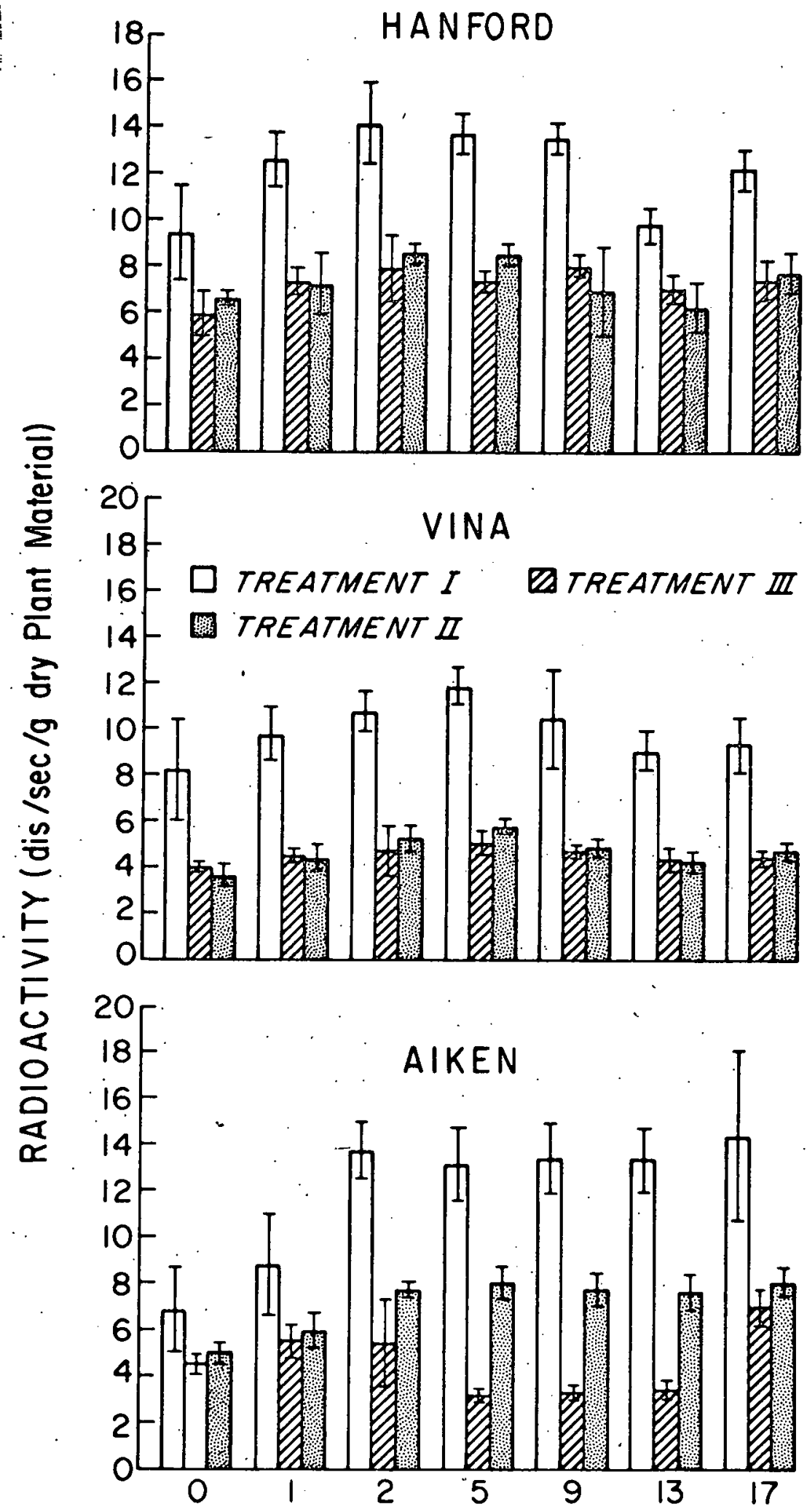

INCUBATION TIME BEFORE CROPPING (WEEKS) 
$\bullet$

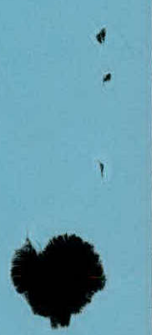

